Available online at: http://proceeding.rsfpress.com/index.php/ic-smart/index

Proceeding on International Conference of Science Management Art Research Technology

(IC-SMART)

Volume 1 Number 1 (2020): 175-181

\title{
Joint Fighting Against Cartel Practices in The Member States of The Regional Economic Zone
}

\author{
Anna Maria Tri Anggraini \\ Faculty of Law, Trisakti University, Jakarta \\ E-mail address: anna.mta@trisakti.ac.id;
}

\begin{abstract}
In general terms, a cartel is considered as a form of agreement between competitors in a similar industry whose purpose is for maximizing profit only for the members of the cartel. There are several principle considerations regarding the establishment of the cartel, such as the mechanism of how the cartel works, how to reveal the cartel and the impact for the competition as well as for the consumers. These understandings are needed in order to handle cartel practices appropriately, both from the aspect of prevention as well as law enforcement. Most of all, countries that are doing an action to fight against cartels will face various obstacles and challenges in order to overcome this practice. The states which are incorporated in a regional economic zone, such as the Association of Southeast Asian Nations (ASEAN), have performed a cooperative action that agrees together to fight against the cartel. This cooperation is executed by doing strategic steps from the level of investigation, starting from detecting, doing a pre-investigation appraisal, investigation planning, and resourcing, as well as making strategies for investigation progress and preparing written recommendations.
\end{abstract}

Keywords: Anti-Monopoly Law, cartel, customers, economic zone

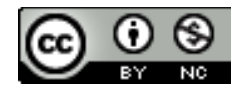

This is an open access article under the CC-BY-NC license

\section{INTRODUCTION}

Cartel activities in strategic sectors have been raising new issues recently in view of the mechanism by which cartels operate, the proving process, and the integrated approach in addressing cartels, both internally with regards to law enforcement agencies, as well as externally involving international cooperation. The mechanism of cartel operations is pointing towards one common feature, namely that cartels are conducted by business actors of similar types belonging to a trade association, for the purpose of maximizing profits based on written or tacit agreement. The existence of such tacit agreement can be considered as a new phenomenon in the proving process using indirect evidence or circumstantial evidence.

Several decisions of the competition authority in Indonesia, namely Komisi Pengawas Persaingan Usaha (Commission for the Supervision of Business Competition) concerning cooking oil cartel (KPPU Decision in Case No. 24, 2009), fuel surcharge cartel (KPPU Decision in Case No. 25, 2009), anti-hypertension medicine cartel (KPPU Decision in Case No. 17, 2010), garlic cartel (KPPU Decision in Case No. 05, 2013), car tire cartel (KPPU Decision in Case No. 08, 2014), poultry cartel (KPPU Decision in Case No. 02, 2016), and imported beef cartel (KPPU Decision in Case No. 10, 
Proceeding on International Conference of Science Management Art Research Technology (IC-SMART), Vol. 1 (1), 175-181

Joint Fighting Against Cartel Practices in The Member States of The Regional Economic Zone Anna Maria Tri Anggraini

2015) have in all instances resulted in excessive prices and have thus unfavorably impacted consumers.

The issue currently being faced by KPPU is when it decides to prove the existence of a collusive agreement by using indirect evidence. The reason for choosing the said mechanism for proving a cartel is, among things, the fact that such agreements are generally entered into tacitly. In addition, KPPU does not have the authority to conduct search and seizure of documents as an investigator would have. In several cases, the courts of law, as the appeals judicature for KPPU decisions, found it difficult to accept indirect evidence, which includes evidence of communication and economic proof, thus frequently leading to the cancellation of KPPU decisions KPPU in cartel cases.

The regional economic area covered by the Association of Southeast Asia Nations (ASEAN) has stepped up economic cooperation within the ASEAN Economic Community (AEC). The AEC has agreed to introduce business competition policies and legislation at the national level in the respective member states by the year 2015, as well as to achieve the objectives of the ASEAN Economic Blueprint. Domestic as well as multinational companies conducting their business activities in the ASEAN region have been under constant pressure to comply with competition laws in the jurisdiction of the country in which they run their operations. It poses certain challenges to the companies concerned, considering the diverse business competition law provisions in each respective country.

ASEAN member states have taken a step towards strengthening cooperation in the field of competition policy and law by establishing the Experts Group on Competition (AEGC). AEGC is a committee formed to oversee the development of competition law and policy in ASEAN. It is expected that by strengthening regional cooperation at the level of ASEAN, competition authorities of member states will be able to share information concerning cartel and anti-competitive practices within such area. That being the case, companies are bound to face further challenges, particularly in cartel investigations, which are based on various different competition laws. Faced with the diversity of the manner in which ASEAN countries deal with cartels, companies need to determine their compliance policy in each jurisdiction, respectively, without constraining themselves by the rigid implementation (Singham, 2017).

\section{THE MECHANISM FOR DEALING WITH CARTELS AND JOINT EFFORTS TO COMBAT CARTELS IN THE MEMBER STATES OF AN ECONOMIC REGION}

The discussion on efforts for combating cartels in member states in areas of economic regions consists of several sub-topics, namely 1 ) the reason for the need to combat cartel practices in strategic industries; 2) the legal mechanism for combating cartels in areas of economic regions; 3 ) potential challenges in establishing mechanisms for joint efforts for combating cartel practices.

The Underlying Rationale of the Prohibition of Cartels under Competition Policy and Law

The prohibition of cartels is provided in several articles, such as Article 5, Article 9, Article 11, and Article 22 of Law Number 5 the Year 1999 concerning the Prohibition of Monopolistic Practices and Unfair Business Competition (Law No. 5/1999) (Article 5, 1999). KPPU's decisions concerning cartel practices in several strategic sectors (such as garlic, tires for four-wheeled vehicles, poultry, import of beef, and even motor vehicles) catering to the needs of many people in the community indicate the same common pattern of behavior, namely that such agreements are entered into verbally and secretly within a trade association. The technique applied by KPPU to reveal and prove such 
Proceeding on International Conference of Science Management Art Research Technology (IC-SMART), Vol. 1 (1), 175-181

Joint Fighting Against Cartel Practices in The Member States of The Regional Economic Zone Anna Maria Tri Anggraini

agreements by using indirect evidence initially raised intensive debate among legal academic circles and observers; however, at the appeal level, the District Court affirmed KPPU's Decision in the fourwheeled vehicle tire cartel case. Indirect evidence was used in the absence of KPPU's authority to seize or search cartel-related documents. Apart from the above, under the provisions prohibiting cartels in Law No. 5/1999, KPPU is obligated to use the rule of reason approach, which requires further economic analysis in order to prove whether or not there is the excessive price or profit resulting in harm to consumers (OECD, 2006).

Parallel to the development of handling cartels in Indonesia, ASEAN member states have also been making endeavors towards the establishment of cooperation in the fight against cartels. ASEAN member states which had adopted the AEC Blueprint in 2007 made a commitment to promote competition policy and law in all ASEAN member states by the year 2015 (Shiau and Chen, 2014). Further development of cooperation was marked by the establishment of Guidelines on Developing Core Competencies Policy and Law for ASEAN Regional Guidelines on Competition Policy in 2010, serving as a priority for AEGC (Asean Secretariat, 2010). Subsequently, at a meeting in Bangkok on November 28-29, 2012, the said document was finalized under the title Guidelines on Developing Core Competencies Policy and Law for ASEAN (The $6^{\text {th }}$ ASEAN Competition, 2016).

For the purpose of implementing the above-mentioned Regional Guidelines, member states agreed to articulate the same in the form of government policy in order to bring immediate impact on the conduct of companies and the structure of the industry in the respective national markets. In principle, competition policy includes two primary elements; first, the adoption of a series of policies to promote competition; second, the adoption of legislation (in the form of laws, court decisions, and implementing regulations) aimed at controlling or prohibiting anti-competitive practices (Asean Secretariat, 2010). The Regional Guidelines are based on the experience of individual countries as well as international best practices. Such Guidelines provide for various policy and institutional choices, which can serve as guidelines for the ASEAN Member States (AMSs) in the context of endeavors towards creating an environment for fair business competition.

In general, the Guidelines set out provisions concerning the objective of establishing the guidelines, the benefits of competition policy, the scope of Competition Policy and Law (CPL), the role and responsibility of competition authorities, law enforcement powers, due process of law, technical assistance and capacity building, advocacy, and international cooperation in the area of competition in the context of free trade agreements. The Guidelines adopted in August 2010 provide for three primary prohibitions, namely (i) anticompetitive agreements; (ii) abuse of a dominant position; and (iii) anticompetitive mergers (and acquisitions). However, neither the EC Blueprint nor the ASEAN Regional Guidelines on Competition have a binding effect on the respective member states (Shiau and Chen, 2014).

\section{Cartel Provisions in the Members States of an Economic Region}

In dealing with cartels, each AMS prohibits anticompetitive agreements through various mechanisms, both from the aspect of the regulatory framework as well as institutional powers. Cartel related provisions include several substantive CPL elements in each member state, namely provisions prohibiting cartels, the competence of competition authorities, and due process of law. Following is an overview of the distinctive features of cartel regulations in the several ASEAN Member States.

Competition provisions in Thailand are set out in The Trade Competition Act B.E 2542 enacted in 1999. Cartel practices are explicitly prohibited in Section 25 and Section 27. Section 25 prohibits agreements for price-fixing, both for predatory pricing as well as excessive pricing, the barrier to 
Proceeding on International Conference of Science Management Art Research Technology (IC-SMART), Vol. 1 (1), 175-181

Joint Fighting Against Cartel Practices in The Member States of The Regional Economic Zone Anna Maria Tri Anggraini

entry, and other acts restring trade. At the same time, Section 27 prohibits price fixing as well as fixing the volume of sales and/or purchases, the division of market territory, as well as bid-rigging.

Provisions on the prohibition of cartels in Vietnam are set forth in the Law on Competition adopted by Parliament on December 3, 2004, which came into effect from July 1, 2005. It was subsequently followed by the issuance of several implementing regulations in the form of Government Regulations. The competition authority in Vietnam is the Administrative Body for Competition, which has the authority to oversee market concentration, to receive jurisdiction for exceptions, to investigate competition cases related to practices restraining competition and unfair competition practices, to impose fines, and to undertake other actions in accordance with applicable law (Competition Law of Vietnam).

The competition authority of Singapore, based on the Competition Act, is the Competition Commission of Singapore (CCS), which has the capacity to sue or to be sued in cases of unfair competition. The main function of the CCS is to promote efficient market behavior by maintaining productivity and competitive culture, raising awareness among government agencies concerning competition policy, as well as other functions including perform such other functions and discharge such other duties as may be conferred on the Commission by or under any other written law (Competition Act, 2004).

Cartel and bid-rigging prohibitions in Malaysia are set out in Part II concerning Anti Competitive Practices, Chapter I concerning Anti Competitive Agreements, Clause (Article) 4 concerning the Prohibition of Horizontal and Vertical Agreements of Act 712 Competition Act 2010. As for the investigation process, it is provided for in Part III concerning Investigation and Enforcement, Clause 14, up to Clause 34. Provisions on the competition authority are set out in Part IV concerning The Malaysian Competition Commission (hereinafter referred to as MyCC), while Part V provides for the Competition Appeal Tribunal.

Similar to Malaysia's competition provisions, Brunei Darussalam has also adopted competition regulations under the Constitution of Brunei Darussalam (Order Made under Article 83(3) Competition Order, in 2015. Prohibited agreements are provided for in Chapter II, including agreements restraining or distorting competition. The said law also provides for a leniency program.

Myanmar began the process of adopting competition rules under The Competition Law (The Pyidaungsu Hluttaw Law No. 9, 2015) The 7th Waxing Day of Taboung, 1376 M.E (February 24, 2015). The powers of the Myanmar Competition Commission as provided for in Chapter V concerning the Power and Duties of The Commission, which basically consists of engaging in cooperation and coordination internationally, in regional organizations or bilateral relations concerning competition matters, determining market share and the volume of supply of companies under investigation. As for cartels, they are in principle provided for in Chapter VII concerning Act of Restraint on Competition, including price-fixing for purchase as well as sale prices, agreements restraining competition, controlling production, and bid-rigging.

All of the above-described components are preventive measures in combating cartels in the form of laws and implementing regulations, supervisory authorities, as well as rules of procedure. The next level of such endeavors includes building synergy, or at at least mutually beneficial harmonization among AMSs, raising awareness of the harmful effects of cartel practices on the community.

\section{Cooperation in Combating Cartels in the ASEAN Region}

The existing diversity of historical background and legislation raises various issues requiring harmonization of implementation at the regional level in the future. One of the central issues is the 
Proceeding on International Conference of Science Management Art Research Technology (IC-SMART),

Vol. 1 (1), 175-181

Joint Fighting Against Cartel Practices in The Member States of The Regional Economic Zone

Anna Maria Tri Anggraini

divergence of legal systems supporting enforcement and the diversity of the organizational structure of competition authorities with jurisdiction in their respective countries. Other significant risks emerging in multi-jurisdictional cases are related to the due process of law and the disclosure of confidential information (OECD, 2012).

There are at least three important points that need to be duly noted in the context of joint investigations of cartels, namely as follows:

a) Application of the principle of comity or mutual respect among countries;

b) Instruments used jointly, in the form of rules concerning joint cartel investigation procedure and mechanism, as well as the effectiveness of the same during a specific time period;

c) The form of competition authority which possesses the powers, competence and independence to overcome the jurisdiction of other member states in implementing its authorities and functions.

The comity principle can be effectively applied through harmonization among member states in the region concerned (Huda et al., 2016). The purpose of harmonizing the regulatory framework is to seek commonalities among the diverse legal systems of member states, subsequently taking steps to complement the same, thus resulting in comprehensive regulations. For such purpose, a combined method of informal and formation cooperation among competition authorities can be adopted. Informal cooperation can include the exchange of information, sharing of knowledge, and strategies for investigation, witness evaluation, market information, or any other matters beneficial for streamlining and directing the investigation process (OECD, 2012).

At the same time, formal cooperation can begin with a memorandum of understanding setting out agreements concerning ways of handling cartels at the regional level. Many countries entering into bilateral agreements include provisions concerning the coordination of parallel investigations, exchange of information, consultations, or exchange of staff between competition authorities (OECD, 2012).

One of the potentially effective methods for revealing cartels within the concept of joint handling of cartel cases, although some member states may not have provided for it, is primarily the guarantee for maintaining the secrecy of information to be revealed by the applicants. With regard to the implementation of cooperation, several countries set forth the legal basis directly for cooperation among authorities or jurisdictions, while others choose to set it out in the cooperation agreement with other jurisdictions. States can also potentially adopt regulations serving as "gateway" to other competition authorities in obtaining information in the course of an investigation conducted by them.

Despite the numerous success stories of cooperation among competition authorities in handling cartel cases, several challenges remain in the implementation thereof. Most national jurisdictions prohibit competition authorities from disclosing confidential information obtained from third parties in the process of investigation. Similarly, in the event of leniency applications, the disclosure of such confidential information may have a potential impact on the applicant's safety. Other potential challenges may arise in view of disparities in the treatment of cartel prohibitions; namely, some states treat cartels as criminal acts, while other states treat cartel cases based on administrative enforcement (Lowe, 2009).

Harmonization at the regional level of the mechanism for proving cartels, followed by the adoption of rules serving as guidelines in handling cartels, is the initial stage in the process undertaken by states in a region. The rules that need to be set out first of all related to cartels include the proceedings, among other things, the hearing mechanism applied by authorities in examining business actors 
suspected of having engaged in cartel activities, the time frame for investigation and examination which is bound to have an impact on limiting the volume of documents and exhibits used by the prosecutor and defense, the scheme of leniency program, and the number of sanctions in the form of fines (Calzado and De Stefano, 2017).

Several countries in a certain region may appoint an institution for investigating cartels involving several competition jurisdictions. The ASEAN region, where almost all member states already have competition law instruments in place, should start thinking about the formation of such competition authority, based on common understanding, and with functions that would include the handling of cross-border cartel cases (OECD, 2012).

\section{CONCLUSION}

Based on the foregoing discussion on handling cartels in economic regions, the following conclusions can be made:

1. All member states in the region have agreed to handle cartels, in view of their highly damaging impact on consumers and the barrier to entry impact on potential new entrants to the market. Member states of the ASEAN Economic Region have agreed to join efforts in combating cartels by adopting anti-monopoly legislation in their respective countries by the year 2015. Such an agreement has been the embryo of cooperation in handling cartels. Harmonization efforts are bound to encounter challenges in the form of the existing divergent legal systems and approaches to cartels in the respective member states.

2. Cooperation in handling cartels in the economic region requires harmonization by developing common understanding, which can be followed up by adopting competition regulations and a supervisory authority at the regional level. There is a need for trained human resources as well as clearly articulated rules concerning the boundaries of the functions and authorities of such an institution.

\section{REFERENCES}

Article 101 of the Treaty on the Functioning of the European Union (TFEU).

Act Number 5 Year 1999 concerning the Prohibition of Monopolistic Practices and Unfair Business Competition.

Competition Act of 2004, Functions and Duties of Commission.

ASEAN Secretariat, "ASEAN Regional Guidelines on Competition Policy”, 2010.

Calzado, Javier Ruiz and Gianni De Stefano, "Rights of Defence in Cartel Proceedings: Some Ideas for Manageable Improvements", Latham \& Watkins - Article Reprint, p.6-8, https://www.lw.com/thoughtLeadership/ rights-of-defence-in-cartel-proceedings, accessed January 16, 2017.

Cassey Lee dan Yoshifumi Fukunaga, "ASEAN Regional Cooperation on Competition Policy", ERIA Discussion Paper Series, http://www.eria.org/ERIA-DP-2013-03.pdf.

Clause 40 of Finding of an Infringement of Competition Act 2010.

He, Jiajie. "Normative Power in the EU and ASEAN: Why They Diverge", International Studies Review (2016) 18, p. 92.

Italianer, Alexander. "Fighting Cartels in Europe And The US: Different Systems, Common Goals", Annual Conference of the International Bar Association (IBA), Boston, October 9, 2013.

Lowe, Philip. "Cartels, Fines, and Due Process", The Online Magazine for Global Competition Policy (GCP), June 2009, Release Two, p.6. 
Mokhamad Khoirul Huda et. al., "Harmonizing Competition Law In The Asean Economic Community", International Journal of Business, Economics and Law, Vol. 9, April 4, 2016, p.5051.

Monti, Mario. "Why should we be concerned with cartels and collusive behaviour?", (Göteborg: Elanders Graphic Systems, 2001), p.15.

OECD, "Improving International Co-operation in Cartel Investigations", Global Forum on Competition, November 30, 2012, p.1.

OECD, "Prosecuting Cartels Without Direct Evidence", DAF/COMP/GF(2006)7, September 11, 2006, https://www.oecd.org/daf/competition/prosecutionandlawenforcement/37391162.pdf, accessed March 17, 2017.

KPPU Decision in Case No. 08/KPPU-I/2014 concerning the Violation of Article 5 paragraph (1) and Article 11 of Law Number 5 Year 1999 in the Automotive Industry related to the FourWheeled Vehicles Tyre Cartel.

KPPU Decision in Case No. 10/KPPU-I/2015 concerning the Alleged Violation of Article 11 and Article 19 sub-article c of Law Number 5 Year 1999 concerning the Prohibtion of Monopolistic Practices and Unfair Business Competition in the Trade of Imported Beef in Jakarta, Bogor, Depok, Tangerang, and Bekasi.

Shiau, Daren and Elsa Chen, "ASEAN Developments in Merger Control", Journal of European Competition Law \& Practice, Vol. 5, No. 3, p.149, 2014.

Singham, Gerald, et. al., "Competition Laws in ASEAN-Overview of The Main Prohibitions", Competition Law Alert, June 2013, file://C:/Users/anna\%20maria/Downloads/Competition\%20Law\%20in\%20ASEAN\%20(2).pdf, accessed March 5, 2017.

The 6th ASEAN Competition Conference, 27-28 July 2016, Bangkok, Thailand. http://asean.org/asean-combat-cartels-region/, accessed March 12, 2017. 